\begin{tabular}{|c|c|}
\hline \multirow{3}{*}{ 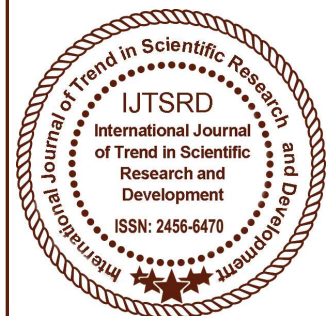 } & $\begin{array}{l}\text { International Journal of Trend in Scientific } \\
\text { Research and Development (IJTSRD) }\end{array}$ \\
\hline & International Open Access Journal \\
\hline & ISSN No: 2456 - 6470 | www.ijtsrd.com | Volume - 2 | Issue - 4 \\
\hline
\end{tabular}

\title{
Pradhan Mantri Jan Dhan Yojana: Finance for all to end "Financial Untouchability" True or Myth
}

\author{
Vikash Chand Jayasawal \\ MBA (Financial Management and Business Laws) \\ Gujarat National Law University, Gandhinagar, Gujarat, India
}

\section{ABSTRACT}

India is country where world's second largest population are using internet, but when we look at number of bank account they show bad figure. Before the launching of PMJDY, $60 \%$ to $65 \%$ populations was unbanked. Only $35 \%$ to $40 \%$ were having a bank account. So for financial development of these peoples, growth of economy, ensure financial services to everyone, there is need of a strong policy with good implementation which can give maximum output. There is need of financial Inclusion. One of the main reasons of poverty in India is financial exclusion also.

Financial inclusion is the essence for the sustainable economic growth and development of the country. Without Financial Inclusion we cannot think of economic development because a large chunk of total population remains outside the growth process. It will solve the problem of financial Untouchability. Indian government and Reserve Bank of India (RBI) are trying from so many years to bring all the people in the ambit of banking. On the eve of 68th Independence Day, Prime Minister Narendra Modi publicized "Pradhan Mantri Jan Dhan Yojana" to reduce financial Untouchability by including millions of people in the financial mainstream. This paper aims to identify the performance of previous financial inclusion schemes, and problems and challenges associated with this PMJDY for ending the Financial Untouchability.

2. Keywords: PMJDY, Swabhimaan, Financial Untouchability, Financial Inclusion

\section{Objective of the Study}

3.1.A comparison of SWABHIMAAN and Pradhan Mantri Jan-Dhan Yojana.

3.2. To find out the benefits of PMJDY to the People, Banks, and Government

3.3.To find out the demerits of this programme.

3.4.Will PMJDY end the 'Financial Untouchability.

\section{Introduction:}

From a long time the Government of India and Reserve Bank of India working aggressive to bring larger section of Indian population within the banking system. Attempts have been made by the Government of India, Reserve Bank of India and Financial Institutions to bring large sections of the rural population within the banking system having realized that financial inclusion is the essence of sustainable economic growth and development in a country like India. Without Financial Inclusion we cannot think of economic development because a large population remains outside the growth process.

In India some peoples are enjoying all kinds of services from savings to net banking, and other side around $40 \%$ of people lack access to even basic financial services like savings, credit and insurance facilities. So there is need of financial Inclusion, and Pradhan Mantri Jan-Dhan Yojana was introduced to solve this problems.

On August 15, 2014 Prime Minister Narendra Modi had announced this scheme on his first Independence 
Day speech. Officially Launched on August 28, 2014. This scheme is run by Department of Financial Services, Ministry of Finance. on the inauguration day, 1.5 Crore (15 million) bank accounts were opened under this scheme. Guinness World Records Recognises the Achievements made under PMJDY, Guinness World Records Certificate says "The most bank accounts opened in 1 week as a part of financial inclusion campaign is $18,096,130$ and was achieved by Banks in India from 23 to 29 August 2014". By 1 June 2016, over 22 crore (220 million) bank accounts were opened and ₹384.11 billion were deposited under the scheme ${ }^{1}$.

The PMJDY providing access to a complete package of financial products, with the saving bank account accompanied with RuPay card. The saving bank account was coupled with an over-draft facility, life insurance policy and an accidental insurance policyall for no fee to the customer.

\section{Historical Background :}

Several countries across the globe now look at financial inclusion as the means for a more comprehensive growth, wherein, each citizen of the country is able to use his/her earnings as a financial resource that they can put to work to improve their future financial status and simultaneously contribute to the nation's progress.

The history of financial inclusion in India is actually much older than the formal adoption of the objective. The nationalization of banks, Lead Bank Scheme, incorporation of Regional Rural Banks, Service Area Approach and formation of Self-Help Groups - all these were initiatives aimed at taking banking services to the masses. The brick and mortar infrastructure expanded; the number of bank branches multiplied ten-fold - from $8,000+$ in 1969 , when the first set of banks were nationalized, to $99,000+$ today. Despite this wide network of bank branches spread across the length and breadth of the country, banking has still not reached a large section of the population. The extent of financial exclusion is staggering. Out of the 600,000 habitations in the country, only about $36,000+$ had a commercial bank branch. Just about 40

\footnotetext{
${ }^{1}$ The Economic Times., 2015. Jan Dhan Yojna makes it to Guinness World

Records, $11.5 \mathrm{cr}$ Jan Dhan accounts opened, Last accessed: September 2, 2016
}

per cent of the population across the country has bank accounts. The proportion of people having any kind of life insurance cover is as low as 10 per cent and proportion having non-life insurance is abysmally low at 0.6 per cent. People having debit cards comprise only 13 per cent and those having credit cards only a marginal 2 per cent of the population.

A more focused and structured approach towards financial inclusion has been followed since the year 2005 when Reserve Bank of India decided to implement policies to promote financial inclusion and urged the banking system to focus on this goal. pacifically, been on providing banking services to all the 600 thousand villages and meeting their financial needs through basic financial products like savings, credit and remittance. The objectives of financial inclusion, in the wider context of the agenda for inclusive growth, have been pursued through a multiagency approach. In 2006, the Government of India constituted a Committee on Financial Inclusion ${ }^{6}$, which made a wide range of recommendations on the strategies for building an inclusive financial sector and gave a national rural financial inclusion plan. Government of India has set up the Financial Stability and Development Council (FSDC), which is mandated, inter alia, to focus on Financial Inclusion and Financial Literacy issues. In order to further strengthen the ongoing financial inclusion agenda in India, a high level Financial Inclusion Advisory Committee has been constituted by RBI. The Committee would pave the way for developing a viable and sustainable banking services delivery model focussing on accessible and affordable financial services, developing products and processes for rural and urban consumers presently outside the banking network and for suggesting appropriate regulatory framework to ensure that financial inclusion and financial stability move in tandem. Financial sector regulators including RBI are fully committed to the Financial Inclusion Mission

\section{Research Methodology :}

The project report aims to analysing that will PMJDY ends Financial Untouchability. The study requires analysis of secondary research data and extensive use of primary data.

The primary data was collected through the servey and questionnaire basis. The primary Data is collected from 2 district of Uttar Pradesh named Jaunpur and Mirzapur. In Data collection it based on a 
questionnaire which consist some question about individual thinking and bank account status. Some unstructured interviews and unstructured conversation in the context of PMJDY, were conducted with the group of people is also used as the source of primary data.

\section{Need of Study :}

By January 2015, the programme claimed near $100 \%$ success on official website (www.pmjdy.gov.in) with district level coverage being published. A data point that stood out was this - the district of Jaunpur and Mirzapur in Uttar Pradesh was one of the few district that showed $100 \%$ coverage. These data points were intresting because mirzapur district has a large population of poor peoples. Peoples who lived in villeges's of mirzapur like Barkachha, belhara they are very poor and living life in very poor condition, they don't have any government scheme's benefits like - govt. toilet, Indira Aawas yojana, and medical facility. They are working on daily basis salary which is near $100-200 ₹ /$ day. So with this low income and lower level of awareness about govt. scheme they are unable to taking benefits of this kind of scheme ${ }^{2}$.

So with this statistic, which is not actual on ground level, led me to ask a questions about this scheme-

- What financial Inclusion mean to someone who is completely financial excluded?

- What is real impact of PMJDY on customers?

- What did customers think of the various features of PMJDY?

So as a student of finance I finalise my research for this project.

\section{Details of Surveyed Villages:}

\begin{tabular}{|l|l|l|}
\hline \multicolumn{1}{|c|}{ District } & \multicolumn{1}{c|}{ Block } & \multicolumn{1}{c|}{ Village } \\
\hline Jaunpur & Sirkoni & Kabulpur \\
\hline Jaunpur & Sirkoni & Kalyanpur \\
\hline Jaunpur & Sirkoni & Shivpur \\
\hline Mirzapur & City Nagar & Barkachha Kala \\
\hline Mirzapur & City Nagar & $\begin{array}{l}\text { Barkachha } \\
\text { Khurd }\end{array}$ \\
\hline
\end{tabular}

More then half of the people surveyed were age between 18-25 years.

9. About the Questionnaire:

Possession of Bank Account

1) Person who have a bank account
1.1) Details of bank account
1.2) Date of opening bank account
1.3) Reasons for opening bank account
1.4) IDs for opening bank account
1.5) Is linked with Aadhar Card?
1.6) Name of Bank

2. Awareness about PMJDY and its features

2.1) Are you know about ATM facility?

2.2) Are you know about Insurance facility?

2.3) Are you know about Over-draft facilty?

2.4) Amount deposited at time of opening account?

3. If you don't have bank account then Reasons?

4. Are $\mathrm{u}$ have a mobile phone with Internet facility?ss

5. Are you using Internet?

6. Others

\section{Evidences and facts from Survey:}

Total 368 household were surveyed from Jaunpur and Mirzapur district of Uttar Pradesh. So there is some results are presented which were found from this survey.

\section{age group of people}

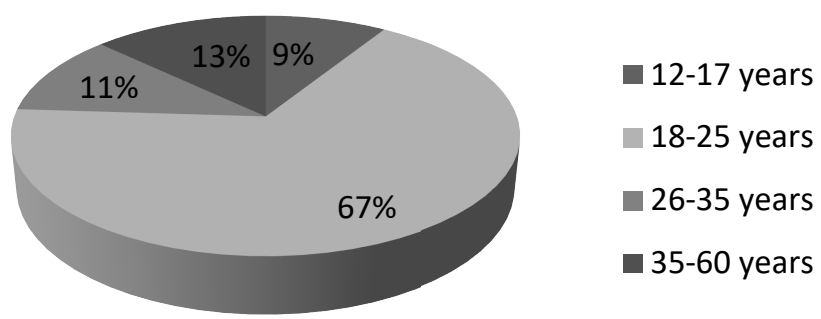

\section{- Age group of people}

\footnotetext{
${ }^{2}$ No of Accounts opened under PMJDY as on 31.01.2015 (Summary),

Last accessed: August 2, 2016
} 


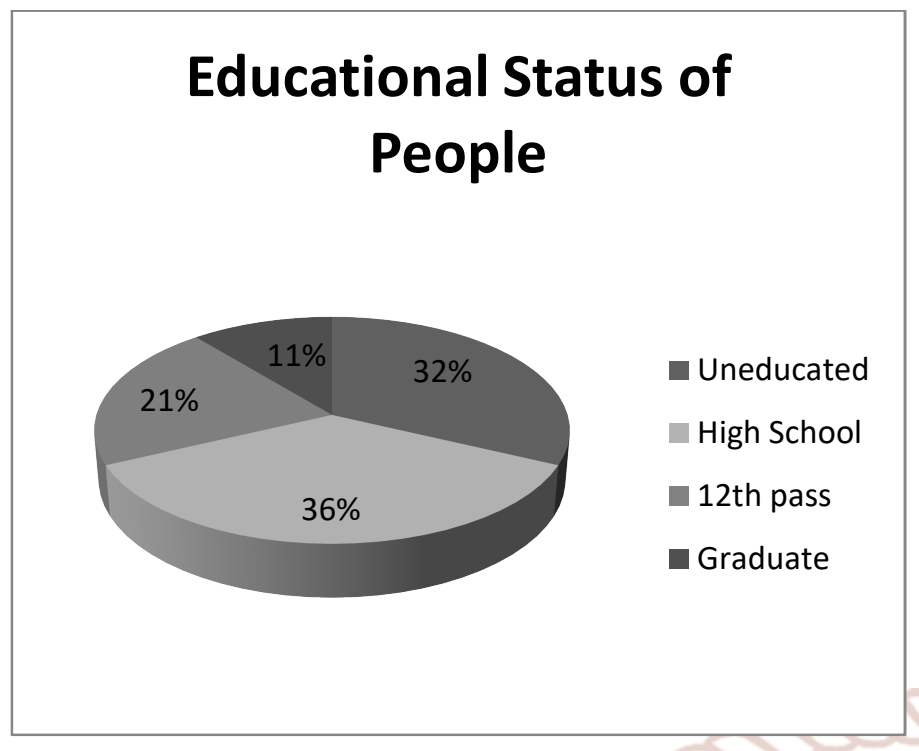

- Educational Status of People

In my survey I found so many people who are uneducated. This is also a reason for people unbanked and financially excluded. If we look about data there is only $11 \%$ of people are graduate. Remaining $89 \%$ people are not graduate and about $32 \%$ people are fully uneducated. If we wants to success of financial inclusion, these situations need to be changed. ${ }^{3}$

\section{Awareness about PMJDY}

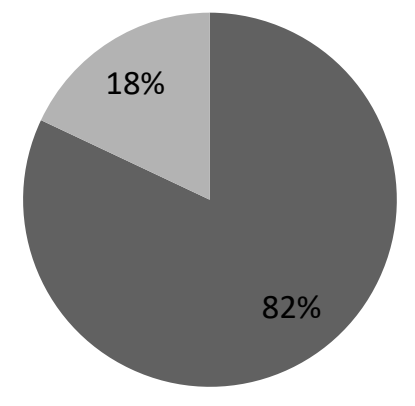

knows

Not knows

In my survey, I found that there are so many people they don't know anything about PMJDY. Some peoples who is only knows that government is opening bank account free, not anything else.

\footnotetext{
${ }^{3} 368$ households were surveyed in all, but 6 households were disqualified

since the person possessing the account was not at home.
}

\section{Bank Account}

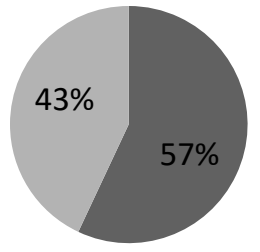

- Have an Account

Don't have an Account

This status showing a positive result. But it is not satisfactory. As we know that before PMJDY, unbanked populations was about to $40 \%-45 \%$. But after coming this scheme there is some changes happened. But there is need more.

\section{Aadhar Status}

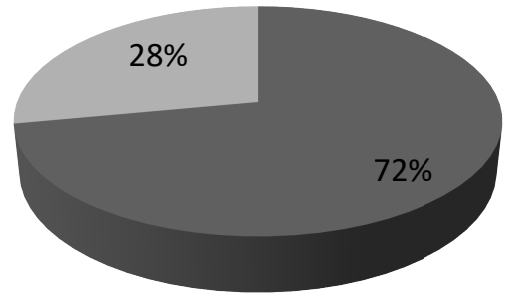

- Linked with AADHAR

Not Linked

\section{- Account Linked with Aadhar}

In my survey I found that there is only $72 \%$ (190 bank accounts) linked with aadhar card. In case of non-link with Aadhar, the account can not identify with biometrically. Some govt. benefits are also not applicable with non-aadhar linked accounts like- Gas subsidy,

\section{Account Opened on Zero Balance}

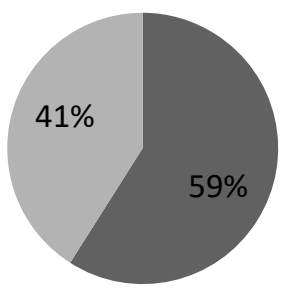

- On Zero Bal. 100-500 ₹ 
This results are showing the status of accounts opened on zero balance. $41 \%$ bank accounts are opened on some deposits. At the time of account opening, banks are demanding some deposits.

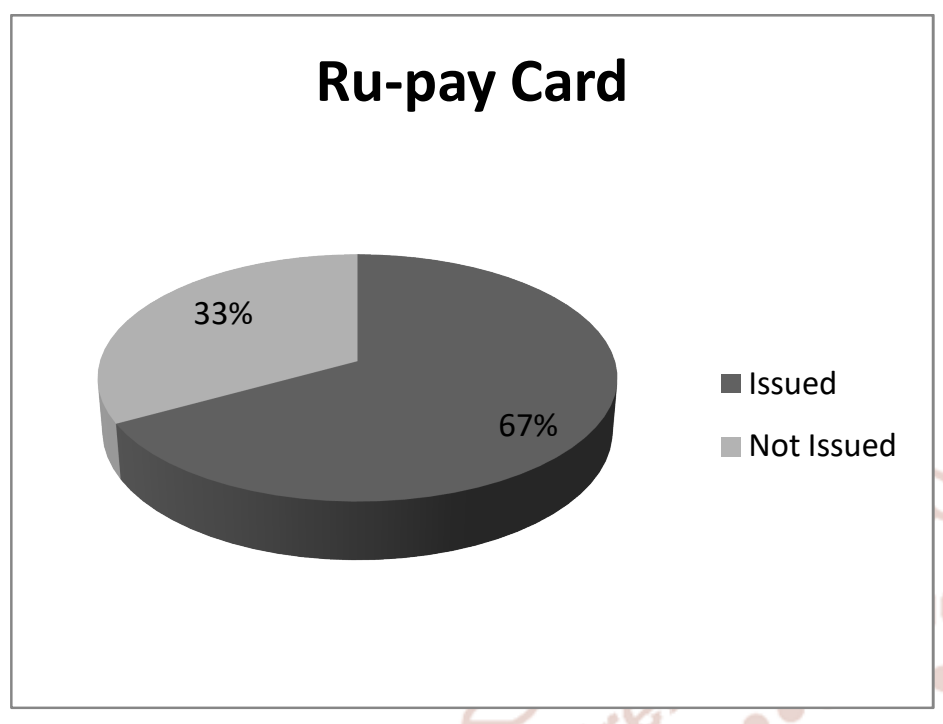

- Rupay Card Issued

This graph is showing number of RuPay card issued with bank account. In case of 55 years above age of people who are uneducated bank are not issuing an ATM card due to fraud and other security issues.

\section{Document submitted to open account}

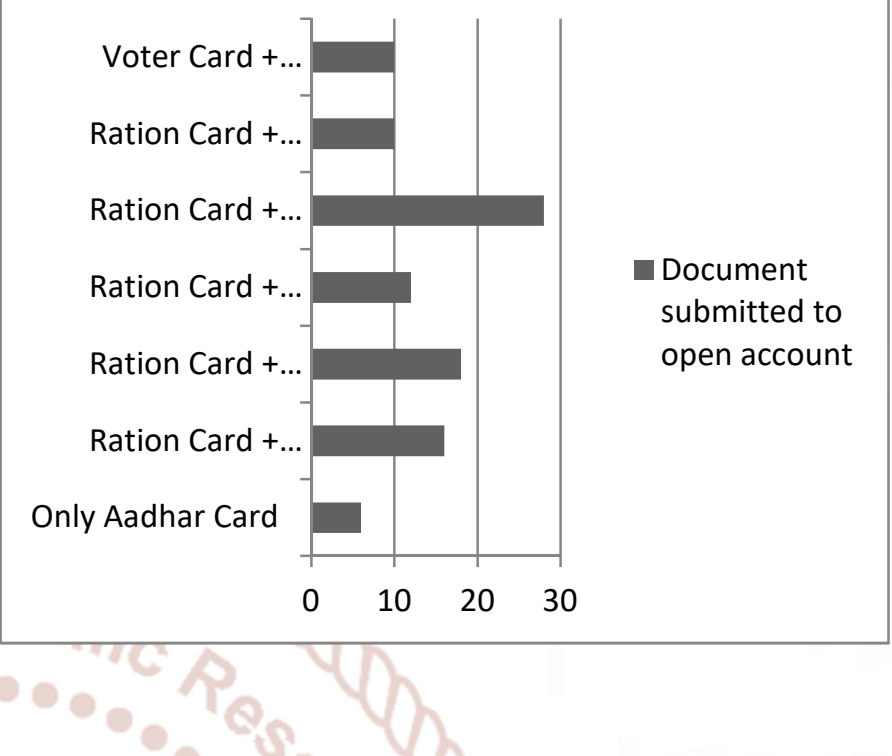

\section{Reason For not having an Account}

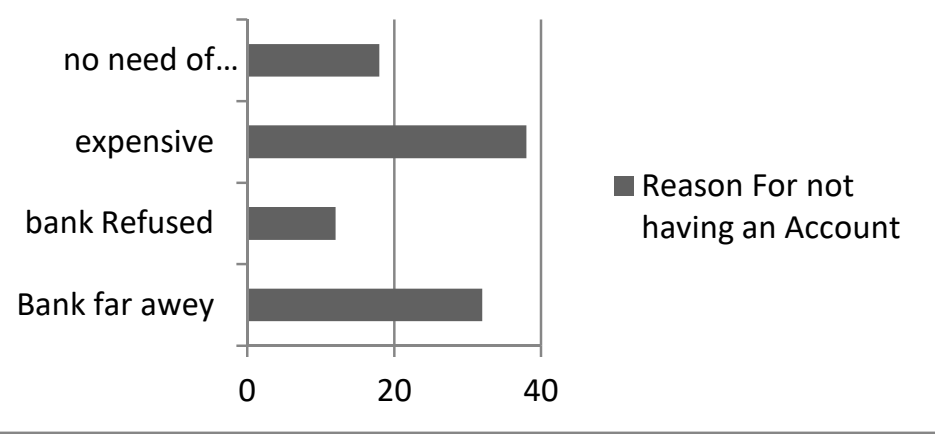

11. Pradhan Mantri Jan-Dhan Yojana's comparison with earlier SWABHIMAAN yojana.

\begin{tabular}{|l|l|}
\hline \multicolumn{1}{|c|}{ Swabhimaan } & \multicolumn{1}{c|}{ PMJDY } \\
\hline $\begin{array}{l}\text { Villages with population greater than } 2000 \\
\text { covered; thus limited geographical coverage }\end{array}$ & $\begin{array}{l}\text { Focus on household; Sub Service Area (SSA) for coverage of } \\
\text { the whole country. }\end{array}$ \\
\hline Only rural & Both rural and urban \\
\hline $\begin{array}{l}\text { Bank Mitr (Business Correspondent) was } \\
\text { visiting on fixed days only }\end{array}$ & $\begin{array}{l}\text { Fixed point Bank Mitr (Business Correspondent) in each } \\
\text { SSA comprising of 1000-1500 households (3 to 4 villages on } \\
\text { an average) to visit other villages in the SSA on fixed days }\end{array}$ \\
\hline $\begin{array}{l}\text { Offline accounts opening - Technology lock-in } \\
\text { with the vendor }\end{array}$ & Only online accounts in CBS of the Bank \\
\hline $\begin{array}{l}\text { Focus on account opening and large number of } \\
\text { accounts remained dormant }\end{array}$ & $\begin{array}{l}\text { Account opening to be integrated with DBT, credit, } \\
\text { insurance and pension }\end{array}$ \\
\hline
\end{tabular}


International Journal of Trend in Scientific Research and Development (IJTSRD) ISSN: 2456-6470

\begin{tabular}{|c|c|}
\hline Inter-operability of accounts was not there & Inter-operability through RuPay Debit Card, AEPS etc. \\
\hline No use of Mobile Banking & Mobile wallet and USSD based mobile banking to be utilized \\
\hline Cumbersome KYC formalities & Simplified KYC/e-KYC in place as per RBI guidelines \\
\hline $\begin{array}{l}\text { No guidelines on the remuneration of the Bank } \\
\text { Mitr (Business Correspondent). Banks went } \\
\text { generally with Corporate BCs who used to be } \\
\text { least expensive to them }\end{array}$ & $\begin{array}{l}\text { Minimum remuneration of the Bank Mitr (Business } \\
\text { Correspondent) to be } 5000 /-(\text { Fixed + Variable) }\end{array}$ \\
\hline $\begin{array}{l}\text { A recent RBI survey finds that } 47 \% \text { of Bank } \\
\text { Mitr are untraceable }\end{array}$ & $\begin{array}{l}\text { Viability and sustainability of Bank Mitr (Business } \\
\text { Correspondent) is identified as a critical component }\end{array}$ \\
\hline Monitoring left to banks & $\begin{array}{l}\text { Financial Inclusion campaign in Mission Mode with } \\
\text { structured monitoring mechanism at Centre, State and } \\
\text { District level }\end{array}$ \\
\hline Financial literacy had no focus & $\begin{array}{l}\text { The rural branches of banks to have a dedicated Financial } \\
\text { Literacy Cell }\end{array}$ \\
\hline No active involvement of states / districts & $\begin{array}{l}\text { State level \& District level monitoring committees to be set } \\
\text { up }\end{array}$ \\
\hline $\begin{array}{l}\text { No brand visibility of the Programme \& Bank } \\
\text { Mitr (Business Correspondent) }\end{array}$ & $\begin{array}{l}\text { Brand visibility for the programme \& Bank Mitr (Business } \\
\text { Correspondent) proposed }\end{array}$ \\
\hline Providing credit facilities was not encouraged & $\begin{array}{l}\text { OD limit after satisfactory operations / credit history of } 6 \\
\text { months Clentillc }\end{array}$ \\
\hline No grievance redressal mechanism & Grievance redressal at SLBC level in respective states ${ }^{4}$ \\
\hline
\end{tabular}

\section{Gaps Bridge by the new Scheme:-}

In the earlier scheme, only villages over and above 2000 population were covered. Under the new scheme, banking services are extended to the whole country by covering sub service area with 1001500 households within a distance of $5 \mathrm{kms}$ using branches and Bank Mitr. Thus, the focus of the earlier plan was more on geographical area and this scheme focuses on households. In the old scheme, bankers worked upon opening of large no. of accounts. therefore, even when the no. of accounts increased, they remained inactive in their operation.

Another is E-KYC, for opening a bank account under PMJDY there is only one id-proof is enough, that is AADHAR Card. Aadhar card is totally based on e-doc which consist biometric identity of user like- figure print, retina scanned identity with other documents like voter id, ration card. Aadhar is bridge between paper identity and bio identity of people. So if any people taking some benefits of govt. scheme illegally through his bank account they will be caught. Mobile Banking and Net Banking facility is also linked with accouts.

\footnotetext{
${ }^{4}$ Taken from http://www.mindmapcharts.com/index.php/blog/366-difference-between-swabhimaan-and-pmjdy
} 
International Journal of Trend in Scientific Research and Development (IJTSRD) ISSN: 2456-6470

13. Benefits of PMJDY to the People, Banks, and Government :-

\begin{tabular}{|c|c|c|c|}
\hline Basic of Banefit & To People & To Bank & To Government \\
\hline $\begin{array}{l}\text { Financial } \\
\text { inclusion }\end{array}$ & $\begin{array}{l}\text { Poor and deprived will be } \\
\text { included in the financial } \\
\text { mainstream }\end{array}$ & $\begin{array}{l}\text { Increase in cash balance } \\
\text { with the banks }\end{array}$ & $\begin{array}{l}\text { Have record of each and every } \\
\text { person }\end{array}$ \\
\hline $\begin{array}{l}\text { Impact on } \\
\text { saving }\end{array}$ & $\begin{array}{l}\text { People motivated to save } \\
\text { more and more in the lure of } \\
\text { safe custody and interest } \\
\text { rate. }\end{array}$ & $\begin{array}{l}\text { Give new wings to } \\
\text { banking business }\end{array}$ & $\begin{array}{l}\text { Mobilize savings which leads to } \\
\text { enhanced circulation of money and } \\
\text { enhance investment in the economy }\end{array}$ \\
\hline $\begin{array}{l}\text { Reduction in } \\
\text { poverty }\end{array}$ & $\begin{array}{l}\text { People get means to earn } \\
\text { livelihood. }\end{array}$ & $\begin{array}{l}\text { Regularity and certainty } \\
\text { of account. }\end{array}$ & $\begin{array}{l}\text { Sustainable and continuous } \\
\text { economic growth. }\end{array}$ \\
\hline $\begin{array}{l}\text { Reduction in } \\
\text { corruption }\end{array}$ & $\begin{array}{l}\text { Direct transfer of benefits } \\
\text { from government to the } \\
\text { beneficiaries }\end{array}$ & $\begin{array}{l}\text { Continuous flow of } \\
\text { money in the new } \\
\text { account and reduces the } \\
\text { chances of NPI's in the } \\
\text { banks. }\end{array}$ & $\begin{array}{l}\text { Reduction of currency printing } \\
\text { expenses and enhances } \\
\text { transparency in work. }\end{array}$ \\
\hline $\begin{array}{l}\text { Reduces the role } \\
\text { of } \\
\text { sahukars and } \\
\text { mahajans }\end{array}$ & $\begin{array}{l}\text { Emancipation of poor } \\
\text { people from the grip of } \\
\text { traditional money lenders. }\end{array}$ & $\begin{array}{l}\text { Enhance lending } \\
\text { business of Banks. }\end{array}$ & $\begin{array}{l}\text { Reduces gap between government } \\
\text { and public and hence leads to social } \\
\text { welfare. }\end{array}$ \\
\hline $\begin{array}{l}\text { Impact of } \\
\text { overdraft } \\
\text { facility }\end{array}$ & $\begin{array}{l}\text { Work as a tool for } \\
\text { emergency assistance. }\end{array}$ & $\begin{array}{l}\text { Enhance additional } \\
\text { source of interest. } \\
\text { ational Journal }\end{array}$ & Increase faith on government. \\
\hline $\begin{array}{l}\text { Economic } \\
\text { growth }\end{array}$ & $\begin{array}{l}\text { Increases employment } \\
\text { opportunities in the long } \\
\text { run. }\end{array}$ & $\begin{array}{l}\text { Expansion of banking } \\
\text { branches and personnel }\end{array}$ & $\begin{array}{l}\text { Attain the objective of reduction in } \\
\text { poverty and attain the objective of } \\
\text { maximum social welfare. }\end{array}$ \\
\hline $\begin{array}{l}\text { Economic } \\
\text { growth Cycle }\end{array}$ & $\begin{array}{l}\text { Deposits of saving ensure } \\
\text { the continuous flow of } \\
\text { economic cycle. }\end{array}$ & $\begin{array}{l}\text { Increased saving with } \\
\text { bank encourage more } \\
\text { and more lending for } \\
\text { investment purposes }\end{array}$ & $\begin{array}{l}\text { Increased investment generates } \\
\text { employment opportunities which } \\
\text { increase income and purchasing } \\
\text { power and give boost to production } \\
\text { and growth cycle continues. }\end{array}$ \\
\hline $\begin{array}{l}\text { Social } \\
\text { upliftment }\end{array}$ & $\begin{array}{l}\text { Raise the living standard of } \\
\text { people and help them to } \\
\text { become the part of } \\
\text { civilization }\end{array}$ & $\begin{array}{l}\text { Accounting of all black } \\
\text { money which proves to } \\
\text { be the effective tool for } \\
\text { development. }\end{array}$ & $\begin{array}{l}\text { Reduction in corruption and } \\
\text { leakages by limiting the role of } \\
\text { middlemen }\end{array}$ \\
\hline $\begin{array}{l}\text { Reduction in } \\
\text { Financial Cost }\end{array}$ & $\begin{array}{l}\text { Risk of carrying and } \\
\text { handling cash reduces. }\end{array}$ & $\begin{array}{l}\text { Less chances of wear } \\
\text { and tear of notes. }\end{array}$ & $\begin{array}{l}\text { Reduction in burden and cost of } \\
\text { printing of currency and helps in } \\
\text { making India green by saving trees. }\end{array}$ \\
\hline $\begin{array}{l}\text { Role of Self- } \\
\text { employment }\end{array}$ & $\begin{array}{l}\text { Two accounts from each } \\
\text { house and the total amount } \\
\text { of overdraft facility will } \\
\text { help poor to start some } \\
\text { small business. }\end{array}$ & $\begin{array}{l}\text { Deposits with banks } \\
\text { increases and chances of } \\
\text { NPA reduce. }\end{array}$ & $\begin{array}{l}\text { Responsibility of government to } \\
\text { provide employment to vast } \\
\text { population decreases upto certain } \\
\text { extent. }\end{array}$ \\
\hline $\begin{array}{l}\text { Strong Financial } \\
\text { Position }\end{array}$ & $\begin{array}{l}\text { Idle deposits circulate in the } \\
\text { economy }\end{array}$ & $\begin{array}{l}\text { Strong financial position } \\
\text { of banks by joining } \\
\text { hands with millions of } \\
\text { financially excluded } \\
\text { People. }\end{array}$ & $\begin{array}{l}\text { Circulation of money increases in } \\
\text { the economy and economy will } \\
\text { become financially strong. }\end{array}$ \\
\hline
\end{tabular}




\begin{tabular}{|l|l|l|l|}
\hline $\begin{array}{l}\text { 'Digital India } \\
\text { Scheme' }\end{array}$ & $\begin{array}{l}\text { Through direct deposit of } \\
\text { subsidies in the account, it } \\
\text { motivates people to change } \\
\text { their lifestyle and step-up } \\
\text { towards modernization. }\end{array}$ & $\begin{array}{l}\text { Limit the role of cash in } \\
\text { an economy. }\end{array}$ & $\begin{array}{l}\text { Complementary to government's } \\
\text { 'Digital India Scheme' as it is move } \\
\text { towards cashless economy }\end{array}$ \\
\hline
\end{tabular}

\section{Demerits of PMJDY: ${ }^{6}$}

14.1. Private Sector Participation below Par: 90 million of 115 million bank accounts are opened by public sector banks. Private sector banks with just 3.6\% of total accounts.5 major private sector banks account for Jan Dhan accounts namely: ICICI, Kotak Mahindra, Yes Bank, IndusInd Bank, Karur Vaisya Bank. PSU banks have greater penetration than private sector banks

14.2. Loan Retrieval: Borrowers are usually from low income families, unorganized sectors of workers and Loan retrieval as well as collection of loan is tough from them. Unpaid loans can damage financial system. One of the biggest lacunae of this scheme is loan retrieval

\subsection{RBI Governor's Concerns:}

\subsubsection{Multiple accounts to get more insurance}

Jan Dhan scheme gives Rs. 1 lakh insurance on each account. To get large insurance or overdraft facility, same person might open multiple accounts in multiple banks- one with Aadhar card, one with PAN card, one with voters card.

Public sector banks may also overlook nuisance, in order to meet their 'targets'. Recall the earlier article on PJ Nayak Committee. Since Government is the majority shareholder in public sector banks $=>$ Chairman and board of directors have pressure from Government $=>$ they pressurize bank staffs to enroll maximum bank accounts so that Modi can brag about it during his Madison square speech.

RBI suggestion: banks should establish a single information sharing system to weed out such multiple accounts

Counter argument: State bank of India has made clear guidelines that even if multiple accounts of same person, he will get only 1 lakh cover. And since all accounts are put under Core banking solution (CBS) platform = duplication / mischief unlikely.

\subsubsection{Insurance thuggary in small fonts-}

Jan Dhan gives you free accident insurance cover worth Rs. 1 lakh. But there is a secret condition- you must use RuPay debit card atleast once every 45 days. This is not be possible for poor families in remote tribal areas. So, they'll lose the benefit due to inactivity.

\section{Why this secret condition}

Because insurance money doesn't fall from sky. Even if you're getting it for free, still someone has to pay the premium, right? In this case, Modi is not paying the premium. (Because he wants to keep fiscal deficit low).Your premium is paid by NPCI. National Payments Corporation of India owns the rupay card system. Therefore, they want you to frequently use the card.

\subsubsection{Business Correspondence Agents}

\footnotetext{
${ }^{5}$ Kumari, J. (2015). Pradhan Mantri Jan Dhan Yojana": An Economic Boost

${ }^{6}$ Prime Minister's Jan Dhan Yojana: Features, Benefits, Criticism. (2014). Mrunal. Retrieved 2 September 2016, from http://mrunal.org/2014/10/banking-pm-jan-dhan-yojana-account-salient-features-benefits-limitations-criticism.html
} 
Jan Dhan aims to divide entry country into sub-service areas (SSA). Within those SSA, each household will have a banking outlet within $5 \mathrm{~km}$ distance. Since banks cannot open branches everywhere, Government aims to achieve this target via Banking Business Correspondence Agents (BCA) or Bank Mitra.

\section{What're the Problem with BCA model?}

1. They get $2 \%$ commission on each transaction. Monthly income $\sim 2000$ rupees.

2. As a result, they quickly lose interest in this game, being some other side jobs. So, BCA are never available when customer needs them. $47 \%$ of the BCA are untraceable. (says RBI survey)

3. Allegations of malpractice. For example

3.1.For opening new account, they ask separate 100 rupees as 'service charge' (although no bank or RBI has authorized such payment).

3.2.Some BCA ask separate commission from illiterate villagers for withdrawing money from account (beyond the official $2 \%$ )

3.3.For loan processing too, they demand separate commission, outside bank's knowledge.

\subsubsection{Direct benefit transfer (DBT)}

PMJDY aims to make all scheme-subsidy payments directly to Jan-Dhan bank accounts. But this Direct benefit transfer (DBT) itself is a failure because:

1. Aadhar project is yet to cover all residents.

2. Aadhar project facing court cases, because UIDAI is not a statutory body, backed by any law.

3. UPA Government had to admit in court that "Aadhar-number" is not compulsory get government-scheme benefits $=>$ people won't be motivated to get Aadhar cards $=>$ Jan Dhan will have trouble transferring money.

4. AT BCA level, Biometric authentication (finger scan) $=$ showing $25-30 \%$ errors. So citizens will have difficulty in withdrawing money even if they've Aadhar card.

\subsubsection{Small Account}

1. If a person doesn't have any official documents, still bank can open its account- with just his photo and signature.

2. But such account will be called "Small account". RBI has put following restrictions on them

2.1.not more than 1 lakh rupee loan per year

2.2.cannot withdraw more than 10,000 rupees per month.

2.3.cannot deposit more than 50,000 rupees in account

2.4. Valid for 12 month only ${ }^{7}$.

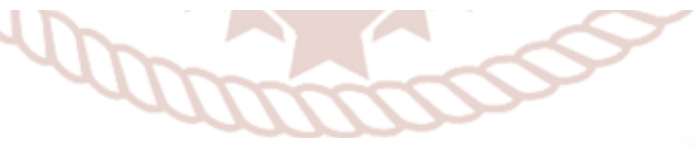

\footnotetext{
${ }^{7}$ Reserve Bank of India,. (2011). Opening of "Small Account". Notification No. 14/2010/ F.No.6/2/2007-E.S. dated December 16, 2010
} 


\section{Will PMJDY end the 'Financial}

\section{Untouchability $^{8}$}

On August 15, India's Independence Day, Prime Minister Narendra Modi announced a national mission of financial inclusion. Called the Pradhan Mantri's Jan-Dhan Yojana - the Prime Minister's People's Wealth Program — it envisions bank accounts for all Indians. "There are millions of families who have mobile phones, but no bank accounts. We have to change this. The change will commence from this point" Said prime minister modi.

Earlier prime ministers had made similar grandiose announcements, with few results. Indira Gandhi started a campaign against poverty, but it never gained traction. Manmohan Singh started a campaign against unemployment, but that failed to take hold as well. The Modi government is still in its honeymoon period; people are willing to accept Jan-Dhan as a plan but not a reachable destination.

On August 28, Modi formally launched the program. Banks across the country had been working overtime to make the necessary arrangements. On the first day, more than 15 million accounts were added. "It is the end of financial untouchability," Modi noted. "It is the beginning of freedom from poverty." It remains to be seen whether the program will lead to big changes. "This is a small step and the take-up is encouraging," says Wharton finance professor Krishna Ramaswamy. "It might lead to small and improved savings in an accountable and hopefully trustworthy way."

The skepticism comes in part due to questions about the veracity of the numbers themselves. RBI governor Raghuram Rajan has publicly warned the banks not to run after records. "We have to make sure the JanDhan Yojana does not go off track," he said at a conference on September 15. "The target is universality, not just speed and numbers."

\section{"India's financial inclusion indicators, particularly in banking, put it below the median of countries, and bank accounts are a first step to inclusion."}

\section{- Rajesh Chakrabarti ${ }^{9}$}

\section{Will Jan Dhan end 'Financial Untouchability'? -} Inclusion. (2014). Inclusion. Retrieved 3 September 2016, from http://inclusion.skoch.in/story/334/will-jan-dhan-endfinancial-untouchability-634.html
According to H.K. Pradhan, professor of finance and economics at XLRI Jamshedpur, there are concerns of duplicate accounts from people who may have opened them "without really understanding what they were doing." He adds that the issue will be sorted out when biometric identification is introduced. But there could be operational complications: Anybody in India can open multiple accounts, so how can there be a different rule for the currently unbanked?

The second - and more important - issue is that India's problem of financial inclusion is gargantuan. According to World Bank data, only $35 \%$ of Indians have an account with a formal financial institution. This is $42 \%$ in the case of men and $27 \%$ for women. Only $8 \%$ have debit cards and $2 \%$ credit cards. According to the government's 2011 Census, 58.7\% households utilize formal banking services.

Rating agency Crisil, a Standard \& Poor's company, has a financial inclusion index called the Inclusix. The all-India Inclusix score is 40.1 (which mean that about $40 \%$ of the country has access to formal banking services). There are wide variations - from $62.2 \%$ in the southern region to $28.6 \%$ in the eastern region.

The high-powered Nachiket Mor committee on Comprehensive Financial Services for Small Businesses and Low-Income Households, set up by the RBI, found that $60 \%$ of the rural and urban population did not have a functional bank account. "India's financial inclusion indicators, particularly in banking, put it below the median of countries, and bank accounts are a first step to inclusion," says Rajesh Chakrabarti, executive director of the Bharti Institute of Public Policy at the Indian School of Business.

The immediate challenge for banks, Pradhan says, will be acquiring the technology needed to facilitate more financial inclusion. "Moreover banks need to convert the old and dormant accounts into the new financial inclusion accounts in order to get the accident coverage and overdraft facility for the account holders." This means that some of the work done on financial inclusion so far will have to be duplicated.

Chakrabarti adds that the government "seems to be fighting the symptoms rather than the disease. The point is for the formal banking system to be present when needed and be superior in convenience and

\footnotetext{
${ }^{9}$ Rajesh Chakrabarti: Faculty at ISB: [Clinical Associate Professor of Finance, ISB (2012 - 2015)
} 
efficiency. However, the approach taken seems to be to lure people into banking through incentives and to hope that the habit sets in. The trouble is that once the sweetener goes away, day-to-day banking provides little benefit in convenience to many users at the bottom of the pyramid."

\section{Suggestion for Policy:}

PMJDY is based on fairly strong principles of financial Inclusion that cannot be found any fault with - access to a formal financial institution through a saving account and prevention of dormancy of the account by linking it to other financial products that are of relevance to a low income household such as Insurance (life and Accidental) and access to emergency needs or cash flow smoothing at the household level.

It has only 2 years since the launch of the PMJDY and there is still time to make programme a success. These are some following recommendations to modify the design and implement of PMJDY that could help the programme meet required results like- financial Untouchability.

16.1. Bureaucracy of Banks- my survey with 368 household across two districts showed that amongst account holder, about 59\% account opened on zero balance, and remaining $41 \%$ accounts opened after depositing amount varying from ₹ 100 to ₹ 1000 . So these need to be changed. If customer wants to open account on zero balance, banks cannot force for deposit some amount for opening an account. Ensuring that the implementation of PMJDY is success requires a massive change management intiation across the banking system. Reducing bureaucracy is a must and can be initiated through a series of on-going training, redesigning incentives and tracking customer satisfaction levels.

16.2. Financial Literacy- for ends the financial Untouchability, opening accounts is not enough. Government should runs some financial literacy programme which will gave some knowledge about savings, loans, financial planning, investment, and other financial terms.

16.3. Financial Capability vs. Financial LiteracyMost policies, including the PMJDY, focus on financial literacy as a means of providing information to customers. In the current implementation, if one were assume that this can be overcome over period of time through mandatory financial literacy programme, it still does not address the larger issue of dormancy of accounts. Reducing financial vulnerability of low income households is possible if one also overcomes institutional barriers to use of financial capability tries to achieve over financial literacy, by enabling not just the 'ability to act', but facilitating the 'opportunity to act'.

\section{Conclusion:}

For ends the financial Untouchability, PMJDY is helpful, but there is also need of some sincere efforts and actual implementation from the side of bank specially rural branches. PMJDY is based on strong principles of financial Inclusion. There is no fault in framing scheme, problem is only at implementation stage. This programme is not only going to benefit the public at large but also to the banks, the government and give boost to the economy. This programme is going to cuts the value of bank's NPAs, boost our economy, by motivating savings which motivates more and more Investment, which motivate employment, this will turn increase the income and purchasing power and living of standard. This programme will lead to effective and optimum utilization of resources and lead to economic growth and development. But it will take time.

And the data, under which the programme is claiming that $100 \%$ household are achieved, it is not true, totally different from ground reality. In reality things are changed because of PMJDY, but still there is lot of changes are remaining if we want to end the financial Untouchability.

PMJDY is greatest steps taken to eradicate poverty by giving major focus on rural India. Successful implementation would not only reduce poverty but also reduce the corruption.if its happen, then the philosophy of NDA's government become true that "Sab ka sath- Sab ka Vikas"

\section{Limitations of the Study:}

This study is depend on survey which was conducted in two district of Uttar Pradesh. So it may be that results are different from the actual conditions of other states or districts. And this survey is represent only the rural areas of these two district. It may be that real condition of urban area is different. 
International Journal of Trend in Scientific Research and Development (IJTSRD) ISSN: 2456-6470

\section{Referances:}

1) (Banking) Prime Minister's Jan Dhan Yojana: Features, Benefits, Criticism. (2014). Mrunal. Retrieved 2 September 2016, from http://mrunal.org/2014/10/banking-pm-jan-dhanyojana-account-salient-features-benefitslimitations-criticism.html

2) DistrictWise House Hold Report. (2015). Pmjdy.gov.in. Retrieved 26 August 2016, from http://pmjdy.gov.in/statewise-statistics

3) Financial Literacy and Credit Counselling Centres (FLCCs)- Model Scheme. (2009) (1st ed.). RBI/ 2008-09/371 RPCD.CO.MFFI.BC.No.86 /12.01.18/2008-09. Retrieved $\bigcirc$ from http://www.pmjdy.gov.in/files/FinancialLiteracy/rbi/scheme.pdf

4) G20 Financial Inclusion Indicators / India $\mid$ The World Bank. (2016). Datatopics.worldbank.org. Retrieved 25 August 2016, from http://datatopics.worldbank.org/g20fidata/country/ india

5) Kumari, J. (2015). Pradhan Mantri Jan Dhan Yojana": An Economic Boost.

6) Measuring Financial Inclusion The Global Findex Database. (2012) (1st ed.). Retrieved from http://documents.worldbank.org/curated/en/45312 1468331738740/pdf/WPS6025.pdf

7) Overdraft upto ₹5,000 ₹ in PMJDY $\mid$ Accounts. (2014) (1st ed., pp. 1-3). Retrieved from http://pmjdy.gov.in/files/QuickLinks/Overdraftfacility.pdf

8) Patnaik, B., Satpathy, I., \& Supkar, A. (2015). PRADHAN MANTRI JAN DHAN YOJNA (PMJDY) - A NEW DIRECTION FOR MAINSTREAMING THE FINANCIALLY EXCLUDED. International Journal of Management (IJM).

9) Pradhan Mantri Jan-Dhan Yojana | Department of Financial Services | Ministry of Finance. (2015). Pmjdy.gov.in. Retrieved 2 September 2016, from http://www.pmjdy.gov.in

10) Reserve Bank of India,. (2011). Opening of "Small Account". Notification No. 14/2010/ F.No.6/2/2007-E.S. dated December 16, 2010.

11) Reserve Bank of India,. (2012). BIS-BNM Workshop on Financial Inclusion Indicators (pp. 6-8). Kuala Lumpur.
12) RuPay Debit Card - Advantages, Application, Benefits to Banks - AllOnMoney. (2014). AllOnMoney. Retrieved 2 September 2016, from http://www.allonmoney.com/banking/rupay-cardadvantages-how-to-get/

13) Shettar, R. (2016). Pradhan Mantri Jan Dhan Yojana: Issues and Challenges. IOSR Journal of Business and Management.

14) Singh, C., Mittal, A., Goenka, A., Goud, C., Ram, K., \& Suresh, R. et al. (2014). Financial Inclusion in India: Select Issues. Bangalore: Indian Institute of Management. Retrieved from https://www.iimb.ernet.in/research/sites/default/fil es/WP\%20No.\%20474.pdf

15) Difference between Swabhimaan and PMJDY. Mindmapcharts.com. Retrieved 29 August 2016, from http://www.mindmapcharts.com/index.php/blog/3 66-difference-between-swabhimaan-and-pmjdy

16) What is Financial Inclusion \& Importance in India. (2016). www.affairscloud.com. Retrieved 2 September 2016, from http://www.affairscloud.com/what-is-financialinclusion-importance-in-india/

17) Will Jan Dhan end 'Financial Untouchability'? Inclusion. (2014). Inclusion. Retrieved 3 September 2016, from http://inclusion.skoch.in/story/334/will-jan-dhanend-financial-untouchability-634.html 